\title{
KANSAS CENTER PIVOT UNIFORMITY EVALUATION OVERVIEW
}

\author{
D. H. Rogers, J. Aguilar, V. Sharda
}

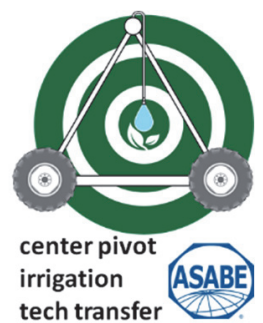

Collection

\begin{abstract}
Center pivot irrigation systems are the most common system type in Kansas for a variety of factors - one of which is the ability to deliver a uniform depth of water application for a variety of crops and field conditions. Uniform applications are dependent on properly designed, installed and operated sprinkler nozzle packages. Uniformity evaluations were conducted as part of the Mobile Irrigation Lab (MIL) project to promote adoption of improved irrigation management practices with an emphasis on ET based irrigation scheduling. Since efficient and uniform water applications are critical to successful irrigation scheduling; MIL assessment included evaluation of sprinkler package performance using a single line catch can test. Catch can data was used to calculate the coefficient of uniformity (CU) and average application depth. The average $C U$ value of the tested systems was 78.7 with a range of from 91.9 to 53.2. Many of the factors affecting pivot uniformity could have been identified and corrected with a visual inspection and/or comparison to the manufacturer's sprinkler design specifications. Some of the catch tests indicated poorly designed and/or maintained sprinkler systems with reduced uniformity directly impacting crop performance, water use efficiency and economic results. Initial information was used in extension programs to illustrate the effect of various correctable sprinkler package deficiencies on performance and to encourage irrigation farmers to examine their nozzle packages and operating conditions.
\end{abstract}

Keywords. Center pivot irrigation, Sprinkler packages, Uniformity.

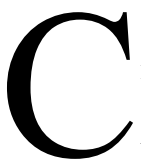

enter pivot irrigation systems are the dominant irrigation system type in use within Kansas (Rogers and Aguilar, 2017). Irrigation is also the dominant use of water supplies in the state, but in many areas of the state, water supplies are diminishing due to declining water table. However, irrigated agriculture provides significant contributions to the economy so improving irrigation water utility and water conservation has long term benefits. Encouraging adoption of improved irrigation management practices, including irrigation scheduling, is a major goal of the K-State Research and Extension (KSRE). In the late 1980's and early 1990's, the development of information networks, communication systems and increasing

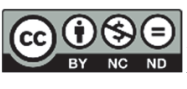

The authors have paid for open access for this article. This work is licensed under a Creative Commons AttributionNonCommercial-NoDerivatives 4.0 International License https://creative commons.org/licenses/by-nc-nd/4.0/

Submitted for peer review in January 2019 as manuscript number NRES 13335; approved for publication as part of the Center-Pivot Irrigation Tech Transfer Collection by the Natural Resources \& Environmental Systems Community of ASABE in May 2019.

The authors are Danny H. Rogers, Professor and Extension Agricultural Engineer, Jonathan Aguilar, Associate Professor and Extension Irrigation Specialist, and Vaishali Sharda, Assistant Professor, Department of Biological and Agricultural Engineering, Kansas State University, Manhattan, Kansas. Corresponding author: Jonathan Aguilar, Kansas State University, Southwest Research and Extension Center, 4500 E. Mary St., Garden City, KS 67846; phone: 620-275-9164; e-mail: jaguilar@ksu.edu. availability of personal computers resulted in making ETbased irrigation scheduling an option for irrigation managers. However, the lack of familiarity of ET-based irrigation scheduling methods, complex scheduling software programs, as well as many farmers' limited skills with computer operation remained as barriers to adoption (Rogers et al., 2002).

On-farm demonstration projects were established in south central and western Kansas to promote ET-based irrigation scheduling using Kansas State University's (K-State) KanSched scheduling tool (Clark et al., 2000). These projects were the forerunners to the Mobile Irrigation Lab (MIL) project which was expanded to include the evaluation of center pivot nozzle packages for uniformity (Clark et al., 2002; Rogers et al., 2002). One rationale for conducting center pivot nozzle package evaluations was that adoption of improved irrigation management techniques, such as ET-based irrigation scheduling, required a uniform application depth to assure that plants had equal access to the applied water and no areas of the field were abnormally either over- or under-watered which would reduce irrigation water productivity.

\section{Procedure}

The majority of the tests were conducted using a single line of catch cans of $10 \mathrm{~cm}$ (4 in.) diameter, called Irrigages (Clark et al., 2004), spaced at no more than $80 \%$ of the sprinkler nozzle spacing but otherwise following the procedure to 
calculate the coefficient of uniformity (CU) as described in ASABE S436.1 (ASABE Standards, 2007) which specifies the CU formula as modified by Heermann and Hein (1968) for use on center pivot sprinkler systems. The Irrigage with a diameter of $10 \mathrm{~cm}$ (4 in.) was constructed with a storage bottle attached to the bottom of the collection barrel to which the water drained after capture. Once in the bottle, evaporation losses were minimal. This allowed data collection that minimized water losses due to evaporation, improved time convenience, and minimized on-site labor.

The collector spacing was selected so a catch sample would be collected within each nozzle spacing interval but with gradual change in the collection location relative to the nozzle outlet. Although the overall CU value could be calculated (Heermann and Hein, 1968), another goal was to document the effect of various operational deficiencies on the performance of the sprinkler package. The center pivot systems initially evaluated were part of a larger demonstration project. Selection criteria for the project field sites included the drive-by visibility of project signage and ease of access for education tours or programs. These systems were also thought to be well maintained and operated at design specifications. Other systems were evaluated at the request of individuals; therefore, these systems were not randomly selected. The intent was to evaluate as many systems as possible following the ASABE S436.1 guidelines (ASABE Standards, 2007) during the MIL program funding period. However many constraints limited the number of evaluations including unfavorable winter weather conditions, spring cultural operations (where a wetted area within the field would not be desirable), operator availability (operators were required to start their systems), crop canopy height, and water right limitations.

Catch can evaluations require sufficient clearance of the nozzle above the top of the collector. A 2009 center pivot survey (Rogers et al., 2009), indicated that over $92 \%$ of the pivots in south central Kansas had nozzle heights of greater than $122 \mathrm{~cm}(4 \mathrm{ft})$ above ground surface and could be tested using the Irrigage catch can evaluation. However, in western Kansas, $60 \%$ of the nozzle packages were located at a height of $122 \mathrm{~cm}(4 \mathrm{ft})$ or less providing insufficient clearance for an Irrigage collector to obtain accurate measurements, since the top of the Irrigage is $41 \mathrm{~cm}$ (16 in.) above ground when installed. Center pivots with sprinkler nozzles mounted too close to the ground for sufficient Irrigage catch clearance were not evaluated.

An analysis of variance (ANOVA) of the coefficients of uniformity was also performed using Microsoft Excel 2016.

\section{RESULTS AND DISCUSSION}

Fifty-three center pivot irrigation sprinkler package evaluations were conducted in Kansas during the period of 19982011 using catch cans. These evaluations were conducted on unique systems, except for tests FI 01A-99. In this instance, the system was tested in the two modes of operation: with the end gun on and with the end gun off. Both values are included in the results. These results are shown in table 1 which includes the general classification of the sprinkler type, collector spacing, the CU and slope of the average application depth, pressure regulation, collector diameter, and the measured region of the system. Also included in the table is the slope of the linear regression line from the catch can depth as a function of distance along the lateral. A slope closer to zero indicates uniform application depth.

The sprinkler types were classified as fixed plate, impact, and moving plate sprinklers. Fixed plate sprinklers are primarily spray nozzles with a splash plate that does not move when impacted by the water stream; while a moving plate sprinkler would have a splash plate that spins, oscillates, or otherwise moves when impacted by the water stream. The number of each sprinkler type tested and the average CU of the systems are shown in table 2. The average CU for the three sprinkler types were similar. Only four impact sprinkler packages were tested and were all operated by one producer. In the center pivot survey by Rogers et al. (2009), only $2 \%$ of the survey observations were impact sprinklers. In some instances tested systems had either wider nozzle spacing on the first span and/or a different sprinkler type on the first span, however the sprinkler type and spacing being reported reflects the package used on the bulk of the system.

The measured ranges of data collection along the center pivots are included in table 1 with the majority of the evaluated systems being approximately $396 \mathrm{~m}$ in length (typically called a quarter mile system). Several irrigation systems were longer including one $804 \mathrm{~m}$ in length (one-half mile system) and one with a corner system (tested with the corner extended). Some systems were tested along the outer spans while others were evaluated over a majority of their length. This range depended on logistical capability, if the evaluators were staying on-site or were able to leave the site and return later for data collection. Applied depths often indicated higher irrigation amounts in the inner most span due to limited nozzle selection, therefore these values were typically excluded from the CU calculation.

Early tests were conducted using $43 \mathrm{~cm}$ diameter pans before the development of the Irrigages. The pans nested for easy transportation and storage and they were easy to install since they only needed to be placed on the ground surface. However, they also needed to be read quickly after an irrigation event to minimize pan evaporation losses. The weight of water collected was used as the measurement method. The pans had to be carried to a weigh station which was labor intensive and tedious. While the average $\mathrm{CU}$ value of the pan catches was higher than the Irrigage catches (table 2), the difference was likely due to the irrigation systems selected for evaluations rather than the collector size itself. Early systems were from project fields thought to be well maintained and/or relatively new compared to later systems tested at the request of producers may have had performance issues. Many of performance issues could have been identified with a visual inspection of the nozzles and/or a comparison of the nozzle package as installed to the sprinkler design package.

Table 2 also includes the average $\mathrm{CU}$ values for pressure regulated (81.7) and non-pressure regulated systems (75.6). In the Kansas center pivot survey (Rogers et al., 2009), about half of the pivots in SC Kansas were pressure regulated and about $80 \%$ in western Kansas. In western Kansas, many of 
Table 1. Coefficient of Uniformity (CU) and slope of linear regression line of catch depth along the collection site and selected test information for various center pivot sprinkler packages of fixed plate, moving plate, and impact sprinklers.

\begin{tabular}{|c|c|c|c|c|c|c|c|}
\hline Test ID & $\begin{array}{l}\text { Type of } \\
\text { Nozzle }\end{array}$ & $\begin{array}{c}\text { Catch Can } \\
\text { Spacing } \\
\mathrm{cm}\end{array}$ & $\begin{array}{c}\mathrm{CU} \\
\%\end{array}$ & $\begin{array}{c}\text { Regression Line } \\
\text { Slope } \\
\mathrm{cm} / \mathrm{m}\end{array}$ & $\begin{array}{c}\text { Pressure } \\
\text { Regulated } \\
\text { Yes or No }\end{array}$ & $\begin{array}{l}\text { Can } \\
\text { Dia. } \\
\mathrm{cm}\end{array}$ & $\begin{array}{c}\text { Collection Site Distance } \\
\text { from Pivot Point } \\
\mathrm{m}\end{array}$ \\
\hline ED 6-01-99 & Fixed & 121 & 86.6 & $-5 \mathrm{E}-05$ & No & 43 & $191-396$ \\
\hline FI 01A -99 EG On & Fixed & 121 & 74.8 & 0.0002 & No & 43 & $144-416$ \\
\hline FI 01A - 99 EG Off & Fixed & 121 & 78.2 & 0.0002 & No & 43 & $144-400$ \\
\hline SV 5-27-99 & Fixed & 121 & 73.2 & 0.0011 & No & 43 & $381-792$ \\
\hline FI 5-26-05 & Fixed & 121 & 72.8 & 0.0004 & Yes & 10 & $266-1306$ \\
\hline FI 4-17-06 a & Fixed & 121 & 77.6 & 0.0033 & Yes & 10 & 4-394 \\
\hline HS 8-05-09 & Fixed & 121 & 81.7 & -0.0027 & Yes & 10 & $6-403$ \\
\hline BT 6-28-10 & Fixed & 121 & 76.3 & $-9 \mathrm{E}-05$ & No & 10 & $90-448$ \\
\hline FI 8-12-11a & Fixed & 121 & 89.5 & 0.0002 & Yes & 10 & $2-404$ \\
\hline ED 6-02-99 & Fixed & 152 & 84.0 & 0.0008 & No & 43 & $201-412$ \\
\hline SN 7-18-02 & Fixed & 183 & 53.2 & 0.0008 & No & 10 & $229-393$ \\
\hline SV 5-12-05 & Fixed & 183 & 79.6 & -0.0002 & $\mathrm{NR}^{[\mathrm{a}]}$ & 10 & $91-395$ \\
\hline FI 5-27-05 & Fixed & 183 & 87.0 & -0.0009 & Yes & 10 & $162-396$ \\
\hline FI 7-02-08 & Fixed & 183 & 86.6 & 0.0018 & Yes & 10 & 7-397 \\
\hline FI 7-17-08 & Fixed & 183 & 91.1 & 0.0008 & Yes & 10 & $51-397$ \\
\hline FI 3-28-08a & Fixed & 183 & 92.1 & 0.0002 & Yes & 10 & $56-395$ \\
\hline FI 4-16-02 & Fixed & 244 & 81.9 & $9 E-05$ & No & 10 & $5-393$ \\
\hline FO 5-16-02 & Fixed & 244 & 58.2 & -0.0042 & No & 10 & $64-403$ \\
\hline SN 6-02-05 & Fixed & 244 & 87.0 & 0.0013 & Yes & 10 & $164-381$ \\
\hline FI 7-19-05 & Fixed & 244 & 75.5 & $-1 \mathrm{E}-05$ & No & 10 & $15-396$ \\
\hline LN 4-21-03 & Fixed & 244 & 71.0 & 0.0006 & No & 10 & $76-391$ \\
\hline RNU01 & Fixed & 244 & 68.6 & 0.0013 & No & 10 & $110-466$ \\
\hline FI 6-14-06a & Fixed & 244 & 71.9 & 0.0026 & Yes & 10 & 7-397 \\
\hline FO 5-27-09 & Fixed & 244 & 86.7 & $-6 E-05$ & No & 10 & $37-424$ \\
\hline FI 7-25-05 b & Fixed & 244 & 71.8 & 0.0031 & Yes & 10 & $41-392$ \\
\hline KI 6-09-99 & Fixed & 121 & 89.9 & 7E-05 & No & 43 & $160-404$ \\
\hline FO 3-13-06 & Impact & 244 & 82.4 & -0.0011 & No & 10 & $80-412$ \\
\hline FO 3-09-06 & Impact & 244 & 72.1 & -0.0007 & No & 10 & $15-407$ \\
\hline FO 4-04-07a & Impact & 244 & 82.4 & -0.0014 & No & 10 & $82-412$ \\
\hline FO $3-30-07 a$ & Impact & 244 & 73.5 & -0.0023 & No & 10 & $82-410$ \\
\hline PR 5-27-99 & Moving & 121 & 84.3 & -0.0007 & Yes & 10 & $179-396$ \\
\hline RN 5-06-11a & Moving & 121 & 90.9 & -0.002 & Yes & 10 & $2-258$ \\
\hline MP GS-1998 & Moving & 152 & 91.8 & -0.0026 & No & 43 & $235-393$ \\
\hline RC-TZ- 1998 & Moving & 152 & 91.9 & -0.0003 & NR & 43 & $223-370$ \\
\hline SG 5-22-02 & Moving & 183 & 83.8 & -0.0011 & No & 10 & $40-369$ \\
\hline SD 6-15-05 & Moving & 183 & 74.1 & 0.0019 & Yes & 10 & $146-369$ \\
\hline FI 7-15-09 & Moving & 183 & 90.9 & -0.0022 & Yes & 10 & $9-347$ \\
\hline GY $4-01-08 b$ & Moving & 183 & 73.8 & 0.0024 & No & 10 & $31-408$ \\
\hline BT 3-27-02 & Moving & 244 & 81.7 & 0.0027 & No & 10 & $99-382$ \\
\hline KI 7-8-02 & Moving & 244 & 76.4 & -0.0009 & Yes & 10 & 104-399 \\
\hline MP 8-21-02 & Moving & 244 & 76.0 & -0.0014 & No & 10 & $111-389$ \\
\hline MP1 8-21-02 & Moving & 244 & 67.0 & -0.0029 & No & 10 & $148-436$ \\
\hline PN 4-01-03 & Moving & 244 & 83.1 & 0.0006 & Yes & 10 & $107-390$ \\
\hline SW 5-15-03 & Moving & 244 & 76.3 & -0.0054 & Yes & 10 & $107-390$ \\
\hline HV $10-05-11$ & Moving & 244 & 79.1 & -0.0011 & Yes & 10 & $54-382$ \\
\hline SG 3-14-03 & Moving & 244 & 65.9 & 0.0005 & No & 10 & $45-391$ \\
\hline FI 7-25-05 & Moving & 244 & 72.2 & -0.0021 & Yes & 10 & $19-433$ \\
\hline RN 6-05-00 & Moving & 305 & 74.5 & 0.0014 & NR & 10 & $192-384$ \\
\hline RN 7-01-00 & Moving & 305 & 88.8 & 0.0023 & Yes & 10 & $258-407$ \\
\hline RC 7-06-00 & Moving & 305 & 72.8 & -0.0018 & Yes & 10 & $165-375$ \\
\hline SF 6-06-00 & Moving & 305 & 88.0 & -0.0025 & NR & 10 & $190-379$ \\
\hline HV 4-10-03 & Moving & 305 & 62.6 & -0.0016 & No & 10 & $117-412$ \\
\hline RN 6-08-02 & Moving & 366 & 65.3 & -0.0005 & NR & 10 & $105-400$ \\
\hline
\end{tabular}

[a] $\mathrm{NR}=$ not recorded

the spray systems are close to the ground and therefore not suitable with a catch can procedure.

The CU values for the various collector spacings are also summarized in table 2 . Initially, the tests were conducted at about $80 \%$ of the nozzle spacing rounded to the nearest foot. Over time, the tests migrated to being conducted at either 122 or $244 \mathrm{~cm}$ (4 or $8 \mathrm{ft}$ ) spacing as a way to streamline the test procedure. There is a tendency for the closely spaced collectors to have higher CU but the data set, especially at wider spacing, is limited.
Figures $1 \mathrm{a}$ and $1 \mathrm{~b}$ are graphs of application depths along the same system (FI 01A - 99, table 1) tested with the end gun on and end gun off, respectively. Figure 1a shows an area of good uniformity until the high catch at radius $288 \mathrm{~m}$. This high catch was due to a leaky tower boot. The next segment of catch shows a gradual decrease in catch until radius $378 \mathrm{~m}$ when application depth increases dramatically. The segment with gradually decreasing application was due to a reversal of the nozzles on the outer two spans, while the sudden increase was caused by over spray from a malfunctioning end gun onto a portion of field covered by the main 
Table 2. Average CU values for center pivot performance evaluations.

\begin{tabular}{lcc}
\hline & CU & $\begin{array}{c}\text { Number of } \\
\text { Observations }\end{array}$ \\
\hline Test Summary of CU & 78.7 & 53 \\
Overall average & 78.7 & 26 \\
Type of sprinkler & 77.6 & 4 \\
Fixed plate average & 78.8 & 23 \\
Impact sprinkler average & & \\
Moving plate average & 77.7 & 45 \\
Size of catch can, diameter & 83.8 & 8 \\
10 cm (4 in.) Catch Can average & & \\
$43 \mathrm{~cm}(17$ in.) Catch Can average & 81.7 & 23 \\
Pressure regulated system & 75.6 & 25 \\
Pressure regulated & 79.9 & 5 \\
Non-pressure regulated & & \\
Not recorded & 81.3 & 12 \\
Catch can spacing & 89.2 & 3 \\
Average $122 \mathrm{~cm}$ & 81.2 & 10 \\
Average $152 \mathrm{~cm}$ & 75.5 & 22 \\
Average $183 \mathrm{~cm}$ & 77.3 & 5 \\
Average $244 \mathrm{~cm}$ & 65.3 & 1 \\
Average $305 \mathrm{~cm}$ & & \\
Average $366 \mathrm{~cm}$ & & \\
\hline
\end{tabular}

lateral. The area of decreasing application depth due to improper nozzle installation is more visible in figure $1 \mathrm{~b}$.

The application depth distribution graph for test PR 5-2799 is shown in figure 2. The CU value for this system is 84.3 . The major problem associated with this system was at the outer edge where the application depth dropped to approximately one-half. This was due to an uninstalled nozzle and under sizing of the orifices of the next two adjacent nozzles in both directions from the uninstalled nozzle. This underwatered area covered approximately $3.7 \mathrm{ha}$. So, for the average water application for this field was $30 \mathrm{~cm}$, this area received around $15 \mathrm{~cm}$ of irrigation instead. A conservative estimate of yield response would be $100 \mathrm{~kg}$ of corn produced per $\mathrm{cm}$ of water use, resulting in an estimated annual field loss of over $12,700 \mathrm{~kg}$ due to a sprinkler package issue that could easily be repaired at minimal cost.

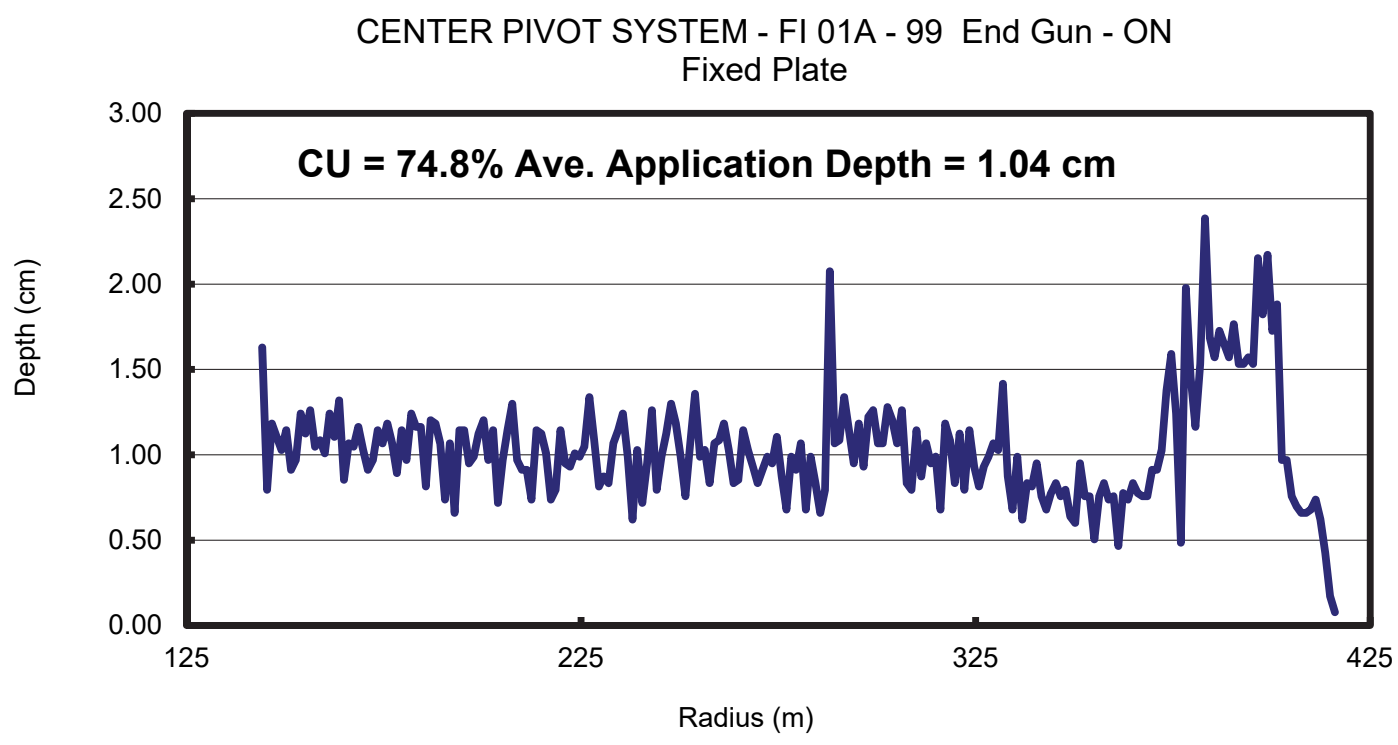

(a)

CENTER PIVOT SYSTEM - FI 01A - End Gun - Off

Fixed Plate

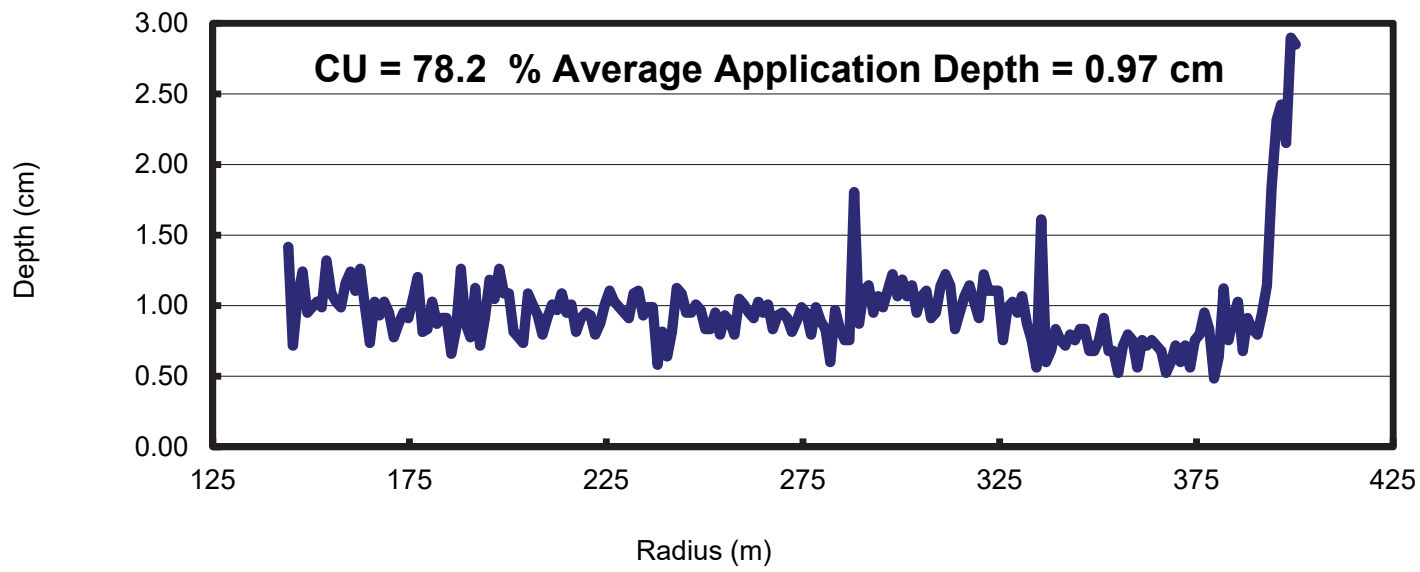

(b)

Figure 1. Catch can uniformity analysis for Center Pivot FI 01A with (a) end gun on and (b) end gun off. 


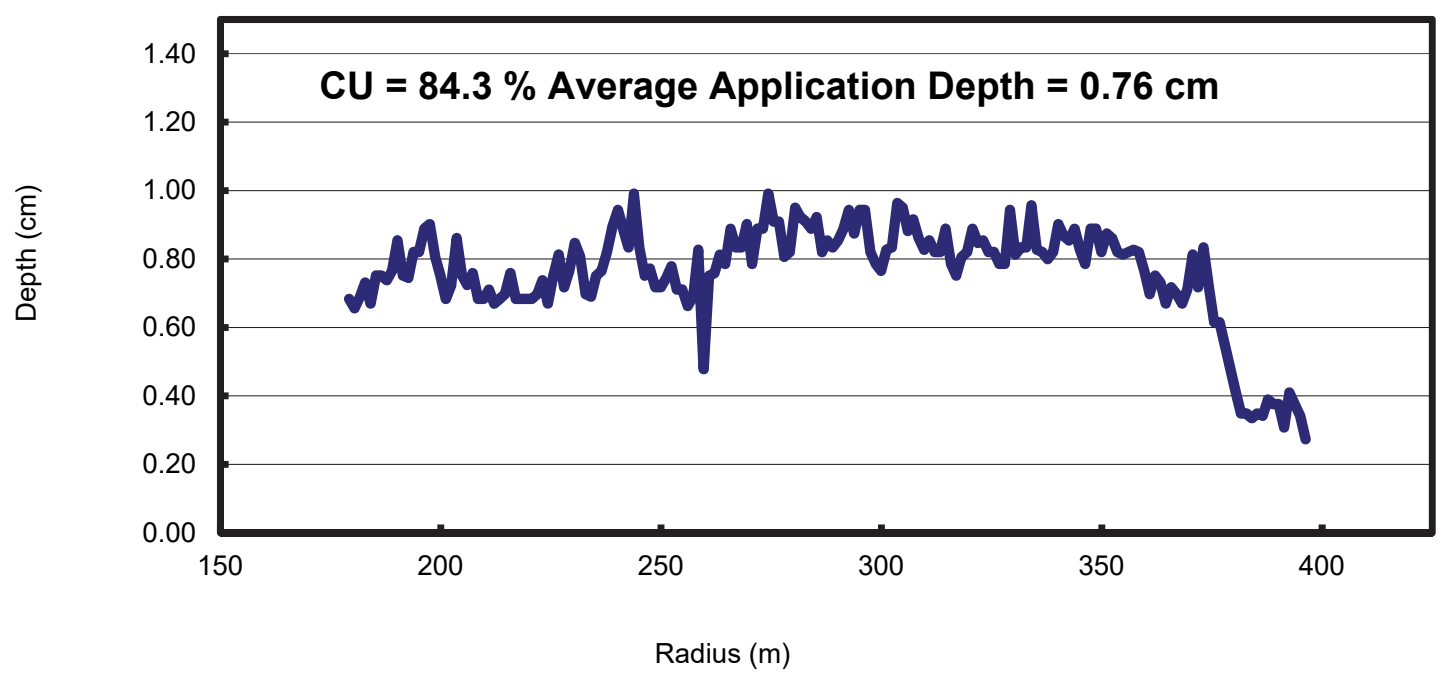

Figure 2. Catch can uniformity analysis for center pivot PR 5-27-99.

Figure 3 shows the graph for center pivot test SN 7-18-99 which had the lowest $\mathrm{CU}$ value of the systems tested $(\mathrm{CU}=$ 53.2). The issue associated with this nozzle package was incrustation build-up within the system and on the fixed plate nozzles (fig. 4). A regular maintenance requirement for this system included unclogging nozzles at the start of irrigation season and the removal of nozzles in the off-season for cleaning of incrustation. Incrustation on the splash plate would interfere with the development of the spokes of water typical for this type of nozzle and prevent proper overlap of the water streams. However, for this very level field, farmed with high residue practices, the applied water was adequately re-distributed on the ground surface as evidenced by the crop appearance (fig. 5).

In some tests, additional catch can container sizes or can spacing configurations were tested, an example is shown in figure 6 for FI 5-26-05. In this example, the $10 \mathrm{~cm}$ Irrigage, $15 \mathrm{~cm}$ Irrigage, and two rectangular troughs, one trough centered on the test spacing and the other placed end to end across the test section were compared with the detail of the

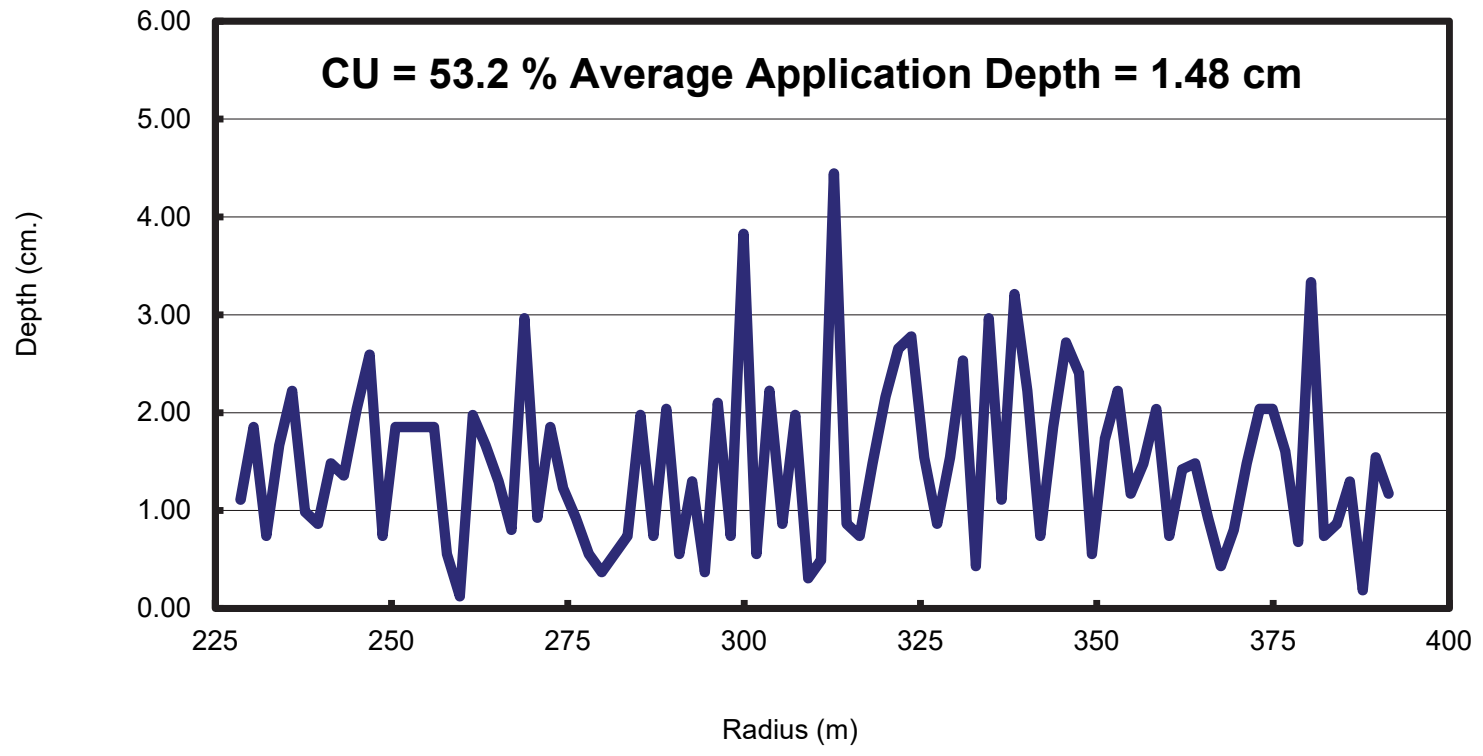

Figure 3. Catch can uniformity analysis for center pivot SN 7-18-99. 

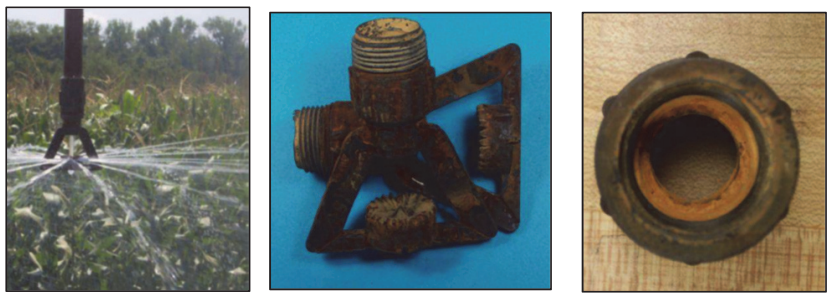

Figure 4. Nozzle incrustation for center pivot SN 7-18-99.

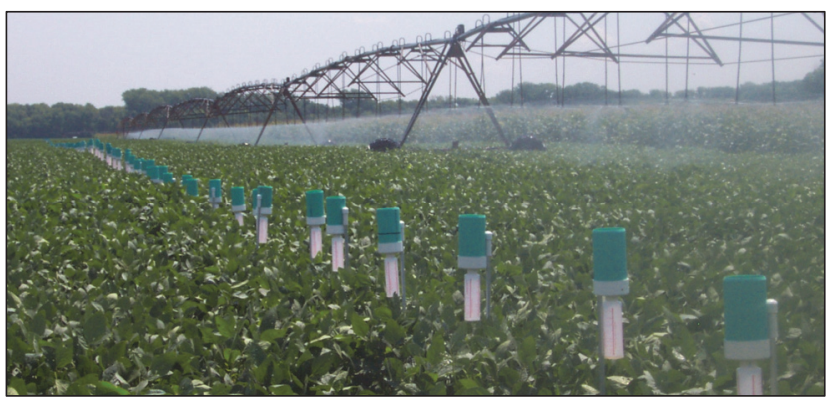

Figure 5. Crop appearance for center pivot SN 7-18-99.

catches shown in figure 6 . This and other systems test sections (not shown) resulted in mixed results, which is consistent with the more rigorous catch can diameter study discussed in the companion article of Rogers et al. (2019). Anecdotal results show the two trough configurations both resulted in higher CU values than either of the irrigages with the end to end configuration obtaining the highest CU, likely due to the averaging of wider catch area as compared to the irrigages.

The ASABE test procedure determining the uniformity of water distribution by center pivots has a maximum can spacing of $3 \mathrm{~m}$ for spray devices and $5 \mathrm{~m}$ for impact sprinklers. The MIL tests were conducted using a single line of cans versus two rows for the ASABE test. Nevertheless, the impact of can spacing on CU was examined by calculating the $\mathrm{CU}$ values for the base can spacing, then every other can (two sets), and every third can (three sets) using the Heermann and Hein (1968) CU formula. The results are shown in table 3, arranged from lowest can spacing to largest spacing.

The first three systems (PR5-27-99, KI 6-09-99, ED 601-99) used a collector spacing of $122 \mathrm{~cm}$ with CU values ranging from 84.3 to 89.9 . Recalculating $\mathrm{CU}$ values for $2 \times$ or $3 \times$ spacing values resulted in less than 1.0 change in $\mathrm{CU}$ as compared to the base $\mathrm{CU}$. The regression lines through the applied depth of catches were very flat and changed little with the increased spacing. In this case, the $2 \times$ catches were with a $244 \mathrm{~cm}$ spacing which is still within the ASABE spacing recommendation but results varied little when going to a $366 \mathrm{~cm}$ spacing, which slightly exceeded the ASABE recommendation.

The next two systems (RC-TZ-1998, ED 6-02-99) had CU values of 91.9 and 84.0 measured at $152 \mathrm{~cm}$ can spacing with a flat regression line for the applied depth of application for the first system, and a positive slope for the second, meaning increasingly more water was being applied with distance from the pivot point. The slope of the regression line was not greatly impacted by can spacing and also there

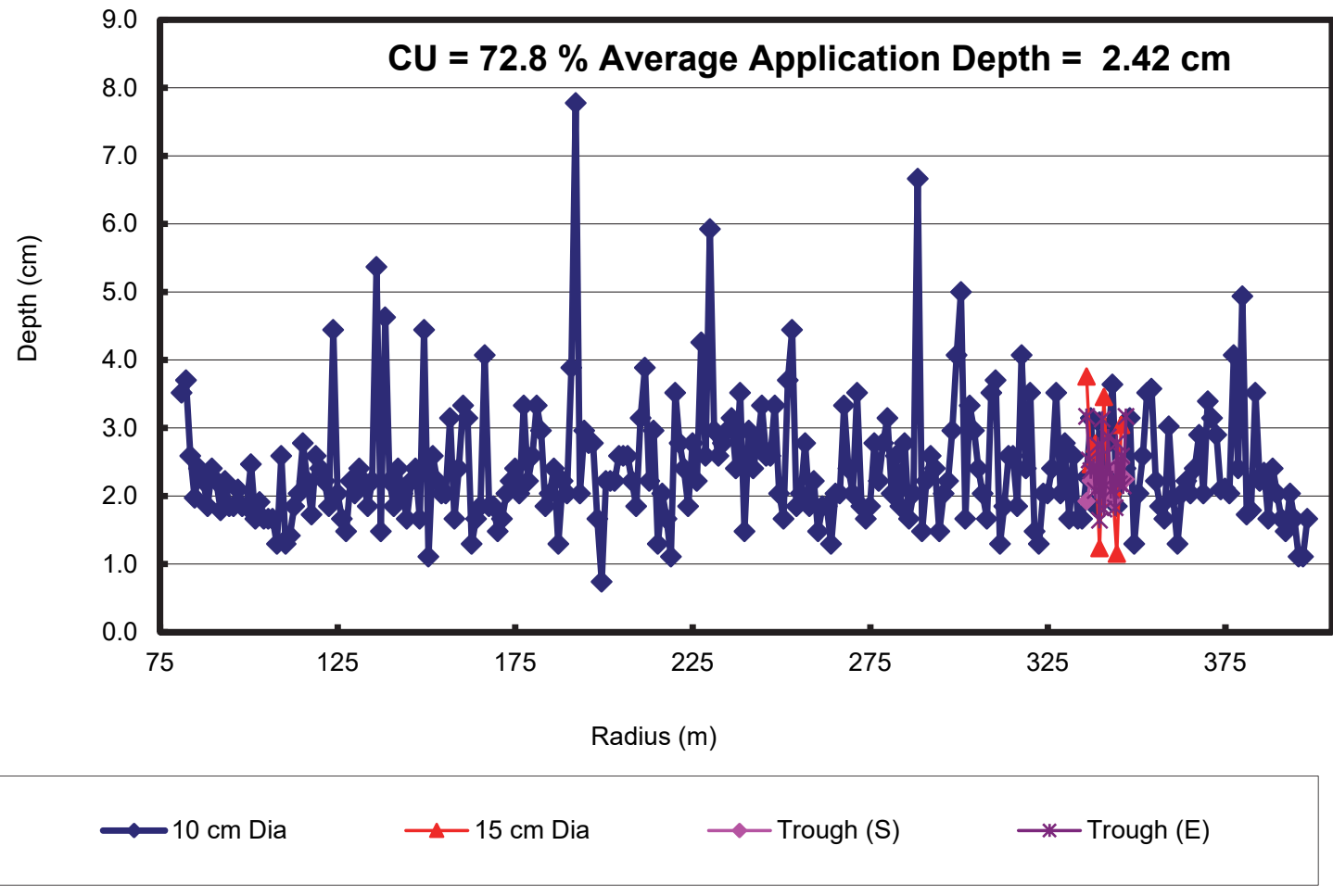

Figure 6. Catch can uniformity analysis for center pivot FI 5-26-05. 
Table 3. Influence of can spacing on CU.

\begin{tabular}{|c|c|c|c|c|c|}
\hline Test ID & $\begin{array}{l}\text { Type of } \\
\text { Nozzle }\end{array}$ & $\begin{array}{l}\text { Collector } \\
\text { Spacing } \\
(\mathrm{cm})\end{array}$ & CU\% & $\begin{array}{c}\text { Applied Depth } \\
\text { Regression } \\
\text { Line Slope }\end{array}$ & $\begin{array}{l}\text { Applied } \\
\text { Depth } \\
(\mathrm{cm})\end{array}$ \\
\hline \multirow[t]{6}{*}{ PR 5-27-99 } & Moving & 122 (Base) & 84.3 & -0.00008 & 0.76 \\
\hline & & 244 (Odd) & 83.8 & -0.00009 & 0.76 \\
\hline & & 244 (Even) & 84.7 & -0.00007 & 0.76 \\
\hline & & $366($ Set 1$)$ & 83.3 & -0.00007 & 0.76 \\
\hline & & 366 (Set 2) & 84.4 & -0.00007 & 0.76 \\
\hline & & 366 (Set 3$)$ & 85.2 & -0.0001 & 0.76 \\
\hline \multirow[t]{6}{*}{ KI 6-09-99 } & Fixed & 122 (Base) & 89.9 & 0.00001 & 0.81 \\
\hline & & 244 (Odd) & 89.7 & 0.00002 & 0.84 \\
\hline & & 244 (Even) & 89.9 & 0.000008 & 0.81 \\
\hline & & $366($ Set 1$)$ & 90.8 & 0.000004 & 0.81 \\
\hline & & 366 (Set 2) & 89.4 & 0.00002 & 0.81 \\
\hline & & 366 (Set 3$)$ & 89.2 & 0.00001 & 0.81 \\
\hline \multirow[t]{6}{*}{ ED 6-01-99 } & Fixed & 122 (Base) & 86.6 & -0.000006 & 1.37 \\
\hline & & $244($ Odd $)$ & 87.2 & 0.000008 & 1.37 \\
\hline & & 244 (Even) & 86.0 & -0.00002 & 1.37 \\
\hline & & 366 (Set 1$)$ & 86.1 & -0.00006 & 1.40 \\
\hline & & 366 (Set 2) & 86.4 & 0.00008 & 1.40 \\
\hline & & $366($ Set 3$)$ & 87.4 & -0.00004 & 1.35 \\
\hline \multirow[t]{6}{*}{ RC-TZ- 1998} & Moving & 152 (Base) & 91.9 & -0.00003 & 2.06 \\
\hline & & 304 (Odd) & 91.2 & 0.00005 & 2.08 \\
\hline & & 304 (Even) & 92.7 & -0.0001 & 2.06 \\
\hline & & $456($ Set 1$)$ & 91.0 & 0.0001 & 2.06 \\
\hline & & 456 (Set 2) & 92.5 & -0.00007 & 2.11 \\
\hline & & 456 (Set 3$)$ & 92.2 & -0.0001 & 2.03 \\
\hline \multirow[t]{6}{*}{ ED 6-02-99 } & Fixed & 152 (Base) & 84.0 & 0.0001 & 1.12 \\
\hline & & 304 (Odd) & 83.9 & 0.00009 & 1.14 \\
\hline & & 304 (Even) & 84.1 & 0.0001 & 1.12 \\
\hline & & $456($ Set 1$)$ & 87.2 & 0.0001 & 1.12 \\
\hline & & 456 (Set 2) & 82.1 & 0.00008 & 1.12 \\
\hline & & $456($ Set 3$)$ & 83.1 & 0.0001 & 1.17 \\
\hline \multirow[t]{6}{*}{ SN 7-18-02 } & Fixed & 183 (Base) & 53.2 & 0.0001 & 1.70 \\
\hline & & 366 (Odd) & 44.6 & -0.0004 & 1.73 \\
\hline & & 366 (Even) & 55.5 & -0.0003 & 1.68 \\
\hline & & $549($ Set 1$)$ & 44.7 & -0.0005 & 1.58 \\
\hline & & 549 (Set 2) & 56.2 & -0.0001 & 1.91 \\
\hline & & $549($ Set 3$)$ & 50.7 & -0.0004 & 1.63 \\
\hline \multirow[t]{6}{*}{ PN 4-01-03 } & Moving & 244 (Base) & 83.1 & -0.00007 & 1.85 \\
\hline & & 488 (Odd) & 77.9 & 0.0002 & 1.85 \\
\hline & & 488 (Even) & 86.5 & -0.0002 & 1.78 \\
\hline & & $732($ Set 1$)$ & 81.3 & 0.000008 & 1.83 \\
\hline & & 732 (Set 2) & 79.2 & -0.000003 & 1.88 \\
\hline & & 732 (Set 3) & 85.4 & -0.00001 & 1.73 \\
\hline \multirow[t]{6}{*}{ LN 4-21-03 } & Fixed & 244 (Base) & 71.0 & -0.00008 & 1.42 \\
\hline & & 488 (Odd) & 70.6 & 0.00008 & 1.45 \\
\hline & & 488 (Even) & 71.5 & 0.00008 & 1.42 \\
\hline & & $732($ Set 1$)$ & 71.8 & 0.000006 & 1.32 \\
\hline & & 732 (Set 2) & 70.0 & 0.0002 & 1.55 \\
\hline & & $732($ Set 3$)$ & 71.5 & -0.000009 & 1.42 \\
\hline \multirow[t]{6}{*}{ MP 8-21-02 } & Moving & 244 (Base) & 76.0 & -0.0002 & 1.75 \\
\hline & & 488 (Odd) & 78.4 & -0.0002 & 1.70 \\
\hline & & 488 (Even) & 74.1 & -0.0002 & 1.83 \\
\hline & & 732 (Set 1$)$ & 80.5 & 0.00007 & 1.68 \\
\hline & & 732 (Set 2) & 72.2 & -0.0003 & 1.80 \\
\hline & & $732($ Set 3$)$ & 75.7 & -0.0003 & 1.80 \\
\hline \multirow[t]{6}{*}{ BT 3-27-02 } & Moving & 244 (Base) & 81.7 & 0.0003 & 1.60 \\
\hline & & 488 (Odd) & 82.6 & 0.0003 & 1.57 \\
\hline & & 488 (Even) & 81.0 & 0.0003 & 1.65 \\
\hline & & 732 (Set 1$)$ & 82.0 & 0.0003 & 1.55 \\
\hline & & 732 (Set 2) & 81.9 & 0.0003 & 1.60 \\
\hline & & 732 (Set 3) & 81.4 & 0.0004 & 1.63 \\
\hline \multirow[t]{6}{*}{ RC 7-06-00 } & Moving & 305 (Base) & 72.8 & -0.0002 & 2.24 \\
\hline & & $610($ Odd $)$ & 72.4 & -0.0001 & 2.26 \\
\hline & & 610 (Even) & 73.1 & -0.0003 & 2.24 \\
\hline & & $915($ Set 1$)$ & 70.9 & 0.0001 & 2.16 \\
\hline & & 915 (Set 2) & 70.2 & -0.0005 & 2.44 \\
\hline & & $915($ Set 3$)$ & 77.8 & -0.0003 & 2.13 \\
\hline
\end{tabular}

was little impact on the average applied application depth. The CU for RC-TZ-1998 had a maximum CU change of 1.5 for both $2 \times$ and $3 \times$ spacing. The $2 \times$ spacing is $304 \mathrm{~cm}$ or approximately the maximum recommended ASABE spacing, while $3 \times$ spacing would exceed the ASABE recommendation. The change in CU value for ED 6-02-99 was only 0.2 at $2 \times$ spacing but as high as 3.2 for the $3 \times$ spacing.

SN 7-18-02, which was discussed previously and shown in figure 3, had a large change in $\mathrm{CU}$ calculation estimates with increased spacing, however with the base can spacing at $183 \mathrm{~cm}$, both $2 \times$ and $3 \times$ catches would exceed the ASABE spacing recommendation. The estimate of applied application depth and the slope of the applied application depth regression line were also impacted by change in spacing.

The next four systems were tested at $244 \mathrm{~cm}$ spacing and the last system at $305 \mathrm{~cm}$, which would be within or near ASABE guidelines. Two systems (LN 4-21-03, BT 3-27-02) showed spacing had little impact on the $\mathrm{CU}$ value. The latter system had a general negative slope towards the application depth. This was thought to be from improper input operating conditions (i.e., on-site flow meter and pressure gauge readings were assumed accurate at the time since it was a new installation and the values were not independently verified; test crews returned to the site at later dates twice but a new catch was never successfully completed). The maximum change in $\mathrm{CU}$ value for the other systems ranged from 7.6 to 8.6 with the largest CU change for the $2 \times$ spacing.

An ANOVA conducted (not shown) on the data from table 3 showed that the can spacing had no significant effect on $\mathrm{CU}$, applied depth or regression slope.

\section{CONCLUSION}

A series of center pivot uniformity evaluations were conducted over multiple years providing a snapshot of the performance of these systems at the time of the test. A single line test with a catch can spacing of less than the sprinkler spacing was used. The systems tested were not randomly selected. The average CU value of the tested systems was 78.7 with a range of from 91.9 to 53.2. Early tests were principally from pivots on producer fields in a demonstration project and tended to have higher $\mathrm{CU}$ values. Latter tests, conducted at the request of producers, tended to be from systems suspected of having performance issues. Many of the factors affecting pivot uniformity could have been identified and corrected with a visual inspection and/or comparison to the manufacturer's sprinkler design specifications. Poorly designed and executed catch tests document the actual uniformity of pivot applications that directly impacts crop performance, water use efficiency and economic results.

Initial information from these tests have been used in meetings and publications to encourage irrigation managers that high CU performance is possible with good package designs, proper operating conditions, and regular sprinkler package maintenance.

\section{ACKNOWLEDGEMENT}

This study was supported in part by The Mobile Irrigation Lab Project GECG 601490, funded by the Kansas Water 
Plan Fund administered by the Kansas Water Office, USDA Project GEGC 601448 and the Ogallala Aquifer Project GEGC 600468.

\section{REFERENCES}

ASABE Standards. (2007). S436.1: Test procedure for determining the uniformity of water distribution of center pivot and lateral move irrigation machines equipped with spray or sprinkler nozzles. St. Joseph, MI: ASABE. Retrieved from http://elibrary.asabe.org/abstract.asp?aid=47816\&t=2

Clark, G. A., Rogers, D. H., \& Briggeman, S. (2000). KanSched: An ET-based irrigation scheduling tool for Kansas summer annual crops. Manhattan: Kansas State University Research and Ext.

Clark, G. A., Rogers, D. H., Alam, M., Fjell, D., Stratton, R., \& Briggeman, S. (2002). A mobile irrigation lab for water conservation: I. Physical and electronic tools. Proc. Irrigation Association International Irrigation Technical Conf.
Clark, G. A., Rogers, D. H., Dogan, E., \& Krueger, R. (2004). The irrigage: A non-evaporating in-field precipitation gage. App. Eng. Agric., 20(4), 463-466. https://doi.org/10.13031/2013.16494

Heermann, D. F., \& Hein, P. R. (1968). Performance characteristics of self-propelled center-pivot sprinkler irrigation system. Trans. ASAE, 11(1), 11-15. https://doi.org/10.13031/2013.39320

Rogers, D. H., \& Aguilar, J. (2017). Kansas irrigation trends. Irrigation management series. MF-2849 (revised). Manhattan: Kansas State Research and Ext.

Rogers, D. H., Aguilar, J., Clark, G. A., \& Wiens, S. W. (2019). Effect of collector size on center pivot water depth catch. App. Eng. Agric., 35(6), 875-880. https://doi.org/10.13031/aea.13311

Rogers, D. H., Alam, M., \& Shaw, L. K. (2009). Kansas center pivot survey. Irrigation management series MF-2870. Manhattan: Kansas State Research and Ext.

Rogers, D. H., Clark, G. A., Alam, M., Stratton, R., \& Briggeman, S. (2002). A mobile irrigation lab for water conservation: II Education programs and field data. Proc. Irrigation Association International Irrigation Technical Conf. 